\title{
IMPLIKASI BUDAYA SEKOLAH TERHADAP PERI KEHIDUPAN AKADEMIS
}

\author{
Isti Nurhayati \\ Tasamuh Institute, Jawa Tengah, Indonesia \\ istinurhayati@gmail.com
}

\begin{abstract}
Abstrak
Kajian penelitian ini bertujuan untuk memperoleh gambaran secara utuh bagaimana sebuah lembaga pendidikan terbuka SMP Alternatif Qoriyah Thoyyibah Salatiga dalam membangun budaya sekolah. Sebuah institusi yang dapat berdiri berdasarkan dukungan lingkungan dan mampu memberikan kontribusi kepada warganya dimana anak-anak mereka mendapatkan pendidikan yang murah, dekat, namun berkualitas. Beberapa rumusan masalah yang akan dijawab diantaranya (1) Bagaimanakah penyelenggaraan pendidikan SMP Terbuka Qoriyah Thoyyibah Salatiga dalam membangun budaya sekolahnya? (2) Bagaimanakah dampak budaya sekolah tersebut terhadap kehidupan akademisnya? (3) Gejala budaya manakah yang berdampak terhadap pembentukan sistem kehidupan akademis yang kondusif? Penelitian ini menggunakan jenis penelitian deskriptif kualitatif dengan pendekatan etnografi. Metode etnografi adalah metode penelitian kualitatif yang mengkaji perilaku manusia dalam setting alamiah dengan fokus interpretasi budaya terhadap perilaku manusia. $\mathrm{Hal}$ ini dpandang tepat menggingat setting sekolah merupakan komunitas budaya atau merupakan komunitas masyarakat yang terdiri dari berbagai macam responden.
\end{abstract}

Kata Kunci: pendidikan, budaya, sistem akademis 
Isti Nurhayati

\begin{abstract}
THE IMPLICATION OF SCHOOL CULTURE TO ACADEMIC LIFE VALUE. This research study aims to obtain a full description about how an educational institution opened in SMP Alternatif Qoriyah Thoyyibah Salatiga to build a school culture. An institution can be established under the support of the environment and able to contribute to its citizens where their children get a cheap, close education and have high quality. The statements of the problem were: (1) How was the provision of SMP Alternatif Qoriyah Thoyyibah Salatiga in building a school culture? (2) What was the cultural impact of the school on academic life? (3) Which cultural symptoms that affect the establishment of a conducive academic life? This research used descriptive qualitative research with an ethnographic approach. It was a qualitative research method that examines human natural attitudes focusing on the culture interpretation toward the human's behavior. It is appropriate since The school setting is cultural community which includes various respondents.
\end{abstract}

Keywords: education, culture, academic systems

\title{
A. Pendahuluan
}

Ada sesuatu yang harus kita cermati dengan proses pendidikan kita. Sebelum sekolah anak terlihat lincah, selalu belajar apa yang diinginkannya dengan riang gembira, menggunakan segala sesuatu yang terdapat di sekitarnya, yang menarik perhatiannya, anak membangun sendiri pengetahuan dan pemahaman lewat pengalaman nyata sehari-hari.

Setelah mereka masuk sekolah, anak dipaksa belajar dengan cara guru dengan suasana tegang, seringkali tidak bermakna, siswa belajar sesuatu yang tidak menarik perhatiannya. Telah terjadi 'penjinakan' pada anak, makin tinggi kelas anak makin kurang inisiatif dan hilangnya keberanian bertanya/ mengemukakan pendapatnya.

Sekolah sebagai pusat kebudayaan akan membentuk tiga wujud kebudayaan dari terwujudnya ide-ide, nilai-nilai, norma-norma, peraturan dan sebagainya, kemudian membentuk suatu aktivitas serta tindakan berpola sebagai masyarakat ilmiah, dan menghasilkan karyakarya. Sampai saat ini kalau kita berbicara mengenai sekolah sebagai pusat kebudayaan maka komponen budaya pembelajaran 
di sekolah perlu mengkaitkan dengan pemahaman siswa terhadap materi ajar dengan lingkungan alamiah di sekitar mereka.

Bagaimana menemukan cara terbaik untuk meyampaikan berbagai konsep yang diajarkan di dalam mata pelajaran tertentu, sehingga semua siswa dapat menggunakan dan mengingat lebih lama konsep tersebut. Bagaimana setiap bagian mata pelajaran dapat dipahami sebagai bagian yang saling berhubungan dan membentuk satu pemahaman yang utuh. Bagaimana seorang guru dalam penciptaan budaya sekolah yang kondusif dapat berkomunikasi secara efektif dengan siswanya yang selalu bertanya tentang alasan dari sesuatu, arti dari sesuatu, dan hubungan dari apa yang mereka pelajari. Bagaimana budaya guru untuk dapat membuka wawasan berpikir yang beragam dari siswa, sehingga mereka dapat mempelajari berbagai konsep dan mampu mengkaitkannya dengan kehidupan nyata, sehingga dapat membuka berbagai pintu kesempatan selama hidupnya.

Ada kecenderungan sekolah sebagai pusat kebudayaan dewasa ini untuk kembali pada pemikiran bahwa anak akan belajar lebih baik jika lingkungan diciptakan alamiah. Belajar akan lebih bermakna jika anak 'mengalami' apa yang dipelajarinya, bukan 'mengetahui'-nya. Pembelajaran yang berorientasi target penguasaan materi terbukti berhasil dalam 'kompetisi mengingat dalam jangka pendek, tetapi gagal dalam membekali anak memecahkan persoalan dalam kehidupan jangka panjang. Dan itulah yang terjadi di kelaskelas sekolah kita.

Sejauh ini pendidikan kita masih didominasi oleh pandangan bahwa pengetahuan sebagai perangkat fakta-fakta yang harus dihafal. Budaya pendidikan kita yang disebut dengan "kelas" masih berfokus pada guru sebagai sumber utama pengetahuan, kemudian ceramah menjadi pilihan utama strategi belajar. Untuk itu, diperlukan sebuah budaya belajar yang lebih memberdayakan siswa. Sebuah budaya belajar yang tidak mengharuskan siswa menghafal faktafakta, tetapi sebuah strategi budaya belajar yang mendorong siswa mengkonstruksikan pengetahuan di benak mereka sendiri.

Budaya mengajar, inilah kata kunci yang sangat mempengaruhi keberhasilan sebuah proses pendidikan, clan mengajar pulalah yang 
menclapat kritik keras dari Paulo Feire dengan model pembelajaran pasif, yakni guru menerangkan, murid mendengarkan, guru mendiktekan, murid mencatat, guru bertanya, murid menjawab dan seterusnya. Paulo Fiere menyebutnya dengan pendidikan gaga bank, yakni pendidikan model deposito, Berta berbagai pengalamannya pada siswa, siswa hanya menerima, mencatat dan men file semua yang disampaikan guru. Pendidikan model bank tersebut menurut Fiere sebagaimana penuturan Ellias dalam Dede Rosyada merupakan salah satu bentuk penindasan terhadap para murid, karena menghambat kreativitas dan pengembangan potensi mereka (Rosyada, 2004: 89).

Dari latar belakang di atas, beberapa rumusan masalah yang akan dijawab melalui penelitian ini diantaranya (1) Bagaimanakah penyelenggaraan pendidikan SMP Terbuka Qoriyah Thoyyibah Salatiga dalam membangun budaya sekolahnya? (2) Bagaimanakah dampak budaya sekolah tersebut terhadap kehidupan akademisnya? (3) Gejala budaya manakah yang berdampak terhadap pembentukan sistem kehidupan akademis yang kondusif?

Mampukah budaya pendidikan yang diciptakan pada lembaga itu memberikan hasil yang setara dengan sekolah unggulan walaupun tanpa fasilitas-fasilitas yang unggul seperti gedung yang megah peralatan pembelajaran yang mewah?, benarkah budaya pembelajaran yang diterapkan menggunakan pendekatan sekolah sebagai pusat kebudayaan yang menciptakan situasi belajar yang nyaman (comfortable learning), belajar yang menyenangkan (enjoyfull learning) dan lain-lain dengan biaya yang terjangkau oleh para siswa yang orang tuanya dari kalangan kelas bawah?.

Melihat latar belakang diatas, penelitian ini bertujuan untuk memperoleh gambaran secara utuh bagaimana sebuah lembaga pendidikan terbuka dalam membangun budaya sekolah. Sebuah institusi yang dapat berdiri berdasarkan dukungan lingkungan dan mampu memberikan kontribusi kepada warganya dimana anak-anak mereka mendapatkan pendidikan yang murah, dekat, namun berkualitas. Dengan gambaran ini dapatkah sekolah model homeschooling ini menjadi sebuah prototype bagi sekolah/ madrasah yang ingin mengembangkan institusinya sebagai lembaga pendidikan alternatif dan sekolah umum lainnya daerahdaerah lain 
ditengah-tengah krisis ekonomi yang melilit bangsa Indonesia saat ini. Temuan ini akan sangat bermanfaat pula bagi kami para dosen tarbiyah yang mengampu mata kuliah Ilmu Pendidikan, Teknologi Pendidikan, Sosiologi Pendidikan, Antropologi Pendidikan dan mata kuliah yang relevan lainnya untuk menambah ilmu pengetahuan dalam pembelajaran di kelas.

Adapun untuk menjawab beberapa pokok masalah diatas, penelitian ini menggunakan jenis penelitian deskriptif kualitatif dengan pendekatan etnografi. Metode etnografi adalah metode penelitian kualitatif yang mengkaji perilaku manusia dalam setting alamiah dengan fokus interpretasi budaya terhadap perilaku tersebut. Karena setting sekolah merupakan komunitas budaya atau merupakan komunitas masyarakat yang terdiri dari tokoh masyarakat, orangtua siswa, siswa, guru, karyawan, komite sekolah, kepala sekolah, dewan pendidikan, pejabat desa dan pejabat Dinas pendidikan, maka perlu disusun langkah-langkah penetapan metode etnografis.

\section{B. Pembahasan}

\section{Hakekat Budaya Sekolah}

Konsep kebudayaan ditampakkan dalam berbagai pola tingkah laku yang dikaitkan dengan kelompok-kelompok masayarakat tertentu, seperti' adat' (custom), atau 'cara hidup' masyarakat. Menurut Marvin Harris, Kebudayaan juga merujuk pada pengetahuan yang diperoleh, yang digunakan orang untuk menginterpretasikan pengalaman dan melahirkan tingkah laku sosial (Spraedly, 1997: 5).

Kebudayaan sebagai suatu sistem makna yang dimiliki bersama, dipelajari diperbaiki, dipertahankan, dan didefinisikan dalam konteks orang yang berinteraksi. Anak-anak memperoleh kebudayaan mereka dengan cara belajar dari orang-orang dewasa dan membuat kesimpulan mengenai berbagai aturan budaya untuk bertingkah laku; dengan kemahiran bahasa, proses belajar itu menjadi semakin cepat. Kebudayaan, baik yang implisit maupun yang eksplisit terungkap melalui perkataan, baik dalam komentar sederhana maupun dalam wawancara panjang. Karena bahasa merupakan alat utama untuk meyebarkan kebudayaan dari satu generasi kepada 
generasi berikutnya, kebanyakan kebudayaan dituliskan dalam bentuk linguistik (Spraedly, 1997: 9 - 11).

J. J. Honigmann dalam bukunya yang berjudul The World of Man membedakan tiga "gejala kebudayaan," yaitu (1) ideas, (2) activites, dan (3) artifacts, sedangkan Kuncaraningrat berpendirian bahwa kebudayaan itu ada tiga wujud, yaitu: (1) Wujud kebudayaan sebagai suatu kompleks dari ide-ide, gagasan, nilai-nilai normanorma, peraturan dan sebagainya. (2) Wujud kebudayaan sebagai suatu kompleks aktivitas serta tindakan berpola dari manusia dalam masyarakat. (3) Wujud kebudayaan sebagai benda-benda hasil karya manusia.

Wujud pertama adalah wujud ideal dari kebudayaan. Sifatnya abstrak, tak dapat diraba atau difoto. Lokasinya ada di dalam kepalakepala, atau dengan perkataan lain di dalam alam pikiran warga masyarakat di mana kebudayaan bersangkutan itu hidup. Kalau warga masyarakat tali menyatakan gagasan mereka dalam tulisan, maka lokasi dari kebudayaan ideal wring berada dalam karangan dan buku-buku hasil karya para penulis warga masyarakat bersangkutan. Sekarang kebudayaan ideal juga banyaktersimpan dalam disk, arsip, koleksi microfilm dan microfish, kartu komputer, silinder, dan pita komputer.

Ide-ide dan gagasan-gagasan manusia banyak yang hidup bersama dalam suatu masyarakat, memberi jiwa kepada masyarakat itu. Gagasan-gagasan itu tidak berada lepas satu dari yang lain, memainkan selalu berkaitan, menjadi suatu sistem. Para ahli antropologi dan sosiologi menyebut system ini sistem budaya, atau cultural system. Dalam bahasa Indonesia terdapat juga istilah lain yang sangat tepat untuk menyebut wujud ideal dari kebudayaan ini, yaitu adat, atau adat-istiadat untuk bentuk jamaknya.

Wujud kedua dari kebudayaan yang disebut sistem sosial atau social system, mengenai tindakan berpola dari manusia itu sendiri. System social itu terdiri dari aktivitas-aktivitas manusia-manusia yang berinteraksi, berhubungan, serta bergaul satu dengan lain dari detik ke detik, dari hari ke hari dan dari tahun ke tahun, selalu menurut pola-pola tertentu yang berdasarkan adap tata kelakuan. Sebagai rangkaian aktivitas manusia-manusia dalam suatu masyarakat, sistem 
sosial itu bersifat konkrit, terjadi di sekeliling kita sehari-hari, bisa diobservasi, difoto, dan didokumentasi.

Wujud ketiga dari kebudayaan disebut kebudayaan fisik, dan tak memerlukan banyak penjelasan. Karena berupa seluruh total dari hasil fisik dari aktivitas, perbuatan, dan karya semua manusia dalam masyarakat, maka sifatnya paling konkret, dan berupa bendabenda atau hal-hal yang dapat diraba, dilihat, dan difoto. Ada bendabenda yang sangat besar seperti pabrik baja benda-benda yang sangat kompleks dan canggih, seperti komputer berkapasitas tinggi; atau benda-benda yang besar dan bergerak, suatu kapal tangki minyak; ada bangunan hasil Beni arsitek seperti suatu candi yang indah; atau ada pula benda-benda kecil seperti kain batik, atau yang lebih kecil lagi, yaitu kancing baju.

Ketiga wujud dari kebudayaan terurai di atas, dalam kenyataan kehidupan masyarakat tentu tak terpisah satu dengan lain. Kebudayaan ideal dan adat istiadat mengatur dan memberi arah kepada tindakan dan karya manusia, menghasilkan benda-benda kebudayaan fisiknya. Sebaliknya, kebudayaan fisik membentuk suatu lingkungan hidup tertentu yang makin lama makin menjauhkan manusia dari lingkungan alamiahnya sehingga mempengaruhi pula pola-pola perbuatannya, bahkan juga cara berpikirnya sungguhpun ketiga wujud dari kebudayaan tadi erat berkaitan, toh untuk keperluan analisa perlu diadakan pemisahan yang tajam antara tiap-tiap wujud itu. Hal ini sering dilupakan; tidak hanya dalam diskusi-diskusi atau dalam pekerjaan sehari-hari ketiga wujud dari kebudayaan tadi sering dikacaukan, melainkan juga dalam analisa ilmiah oleh para sarjana yang menamakan dirinya ahli kebudayaan atau ahli masyarakat, dan sering tidak dapat dibuat pemisahan yang tajam antara ketiga hal tersebut.

Seorang sarjana antropologi dapat meneliti hanya dari sistem budaya atau adat, dari suatu kebudayaan tertentu. Dalam pekerjaan tsb meng-khususkan perhatiannya terutama pada cita-cita, nilai-nilai budaya, dan pandangan hidup, norma-norma hukum, pengetahuan dan keyakinan dari manusia yang menjadi warga masyarakat yang bersangkutan. la dapat juga meneliti tindakan, aktifitas-aktivitas dan karya manusia itu sendiri, tetapi dapat juga mengkhususkan 
perhatiannya pada hasil dari karya manusia yang bisa berupa benda peralatan, benda kesenian, atau bangunan-bangunan.

Menurut Raymond Williams, istilah "kebudayaan" merupakan salah satu istilah yang tersulit untuk didefinisikan. Tidak ada kesepakatan mengenai arti istilah itu Kata "cultura" (latin) atau "culture" (Inggris), terkait dengan istilah "kultivasi", pembudidayaan. Kebudayaan mengimplikasikan suatu "proses", suatu "perkembangan" (mengenai asal-usul dan perkembangan arti istilah "cultura, lihatlah Raymond Williams, Keywodrs, A Vocabulary of Culture and Society, New York, Oxford University Press, 1983).

"Kebudayaan" dapat dimengerti sebagai "makna sosial yang dihayati bersama”, yaitu berbagai cara kita memaknai dunia. Tetapi makna tidak berada di "awang-awang", tetapi dilahirkan oleh melalui "tanda-tanda” (signs). Maka kajian mengenai kebudayaan berkaitan dengan kajian mengenai pemaknaan (semiotika). Ini berarti bahwa kajian mengenai kebudayaan tidak dapat tepas dari kajian mengenai bahasa. Bahasa memberi makna kepada objek material dan praktek sosial. Dengan lain perkataan, memahami kebudayaan berarti menyidiki bagaimana makna diproduski secara simbolik sebagai bentuk representasi.

Mempelajari kebudayaan terutama dalam "cultitral studies" berarti mempelajari cars-cars bagaimana dunia secara sosial dikonstruksi-kan dan direpresentasikan kepada dan oleh kita. Dengan lain perkataan kebudayaan adalah studi semiotik, yaitu studi mengenai berbagai corak representasi, yaitu sistem simbolik dan sistem pemaknaan (sigifying systems), melalui mana tatanan sosial diproduksi dan dikomunikasikan konsep semiotik kebudayaan, menurut Clifford Geerz, memahami bahwa manusia adalah "art animal suspended in webs of significance he himself has spun". Kebudayaan adalah jaringan makna clan studi mengenai makna tersebut "bukanlah suatu ilmu eksperimental yang berusaha mencari hukum tetapi ilmu interpretatif yang berusaha mendapatkan makna” (Geerz, 1973: 5). Ini berarti menggunakan hermeneutika, filosofis, genealogi (Foucault) kritik sastra dan pendekatan historis dalam kajian konstruksi sosial realitas.

Setiap tindakan manusia bersifat simbolik. Karena manusia 
memahami dirinya sendiri, aktivitasnya dunianya sebagai sesuatu. Konsepsi atau pemahaman tersebut menjadi dasar dari "aktivitas produktif. Yang dimaksud dengan aktivitas produktif adalah aktivitas yang melibatkan hubungan manusia dengan alam yang pada akhirnya menghasilkan suatu "objek" (objektifikasi). Tanda simbol dan ide, "produksi material" tak akan memiliki kehidupan (Marx menyatakan bahwa kerja menjadikan "materi" hidup), energi, kepentingan dan tak akan menimbulkan harapan bahkan ketamakan. Kegiatan produktif itu karena memuat simbol clan gagasan, menjadi realitas yang hidup dan memiliki kekuatan sendiri, sehingga tumbuh menjadi "kapitalisme industrial", yaitu suatu masyarakat dimana faktor-faktor eknomis ditangkap sebagai kekuatan yang besar clan otonom (Marx berbicara mengenai "fetisisme").

Bahasa menjadi penting untuk memahami kebudayaan: pertama, bahasa adalah medium utama di mana makna budaya dibentuk dan dikomunikasikan; kedua, bahasa adalah saran utama dan medium melalui mana kita membentuk pengetahuan mengenai diri kita dan dunia sosial kita. Bahasa membentuk jejaring dengan mans kita mengklasifikasi dunia dan membuatnya bermakna, yaitu menjadi kebudayaan.

Ferdinand de Saussure pada awal abad 20 berusaha memaharni bahasa sebagai suatu keseluruhan sistemik clan tidak bisa direduksi dalam suatu tuturan tertentu. Bukunya Course iin General linguistics (1915) dikumpulkan oleh mahasiswanya dari kuliahnya yang diberikan antara tahun 1906-1911. De Saussure membedakan bahasa sebagai "fakta sosial" (la longue), berbagai tuturan, speech events (la paroke) dan kumpulan tuturan dan aturanaturan bahasa (gramatika), suatu sistem yang mengatur bahasa (le langage). Bahasa merupakan suatu sistem tanda (sign) yang terdiri alas penanda (signifier) dan yang ditandakan (signified). Bila saga mengucapkan suara "macan" dan menulis "macan", ini merupakan penanda, (signifier). Konsep "binatang yang buas” merupakan yang ditandakan (sigified). Tanda mempunyai makna karena hubungan antara penanda, dan yang ditandakan. Tidak ada hubungan alami antara penanda clan yang ditandakan kaitannya arbitrer dan konvensional. Bahasa tidak mencerminkan suatu realitas yang ada sebelumnya; juga tidak mewakili konsep universal yang ada ataupun 
semua kebudayaan. Apa yang membuat suatu tanda bermakna bukan sifat intrinsiknya.

Makna adalah produk dari perbedaan antartanda dan hubungan dengan tanda lainnya. Suara memainkan peran peting dalam membekali tanda dengan makna alas dasar perbedaan. Perbedaan antara "dog" dan "fog" yang memungkinkan kita mcmberi makna yang berbeda. Perbedaan makna datang dari perbedaan antar tanda dan keberadaannya dalam sistem. Saussure membandingkan bahasa dengan catur. Pion-pion dalam pagan catur tidak mempunyai arti di luar aturan permainan. Setiap pion hanya mempunyai makna dalam hubungan dengan pion lainnya, sebagaimana halnya bahasa, setiap tanda mendapatkan makna dalam hubungan dengan tanda lainnya. Kalimat dikonstruksikan melalui seleksi dan kombinasi. Pandangan Saussurian ini disebut strukturalisme semiotik atau strukturalisime linguistic Jacques Derrida merupakan pengritik linguistik Saussurian. Derrida menunjukkan sistem perbedaan yang mewujudkan suatu bahasa tidak bersifat tetap. Suatu pertanda (signifer) tidak begitu saja merujuk kepada suatu yang ditandakan (signified), yang ada di kepada seorang pembicara, atau pendengar. Ide atau konsep tentang tempat duduk dengan empat kaki, tidak sepadan penuh dengan penanda "kursi". Derrida berpendapat bahwa makna suatu istilah selalu bergeser sejalan dengan rangkaian makna yang, mungkin. Yang ditandakan (konsep, makna) selalu ditunda. Tidak ada "makna (signified) transendental". Tak ada makna yang menghentikan arus makna, yang menahan permainan pemaknaan.

\section{Hakekat pendidikan}

Dalam arti sederhana pendidikan diartikan sebagai usaha manusia untuk membina kepribadiannya sesuai dengan nilai-nilai di dalam masyarakat dan kebudayaan. Dalam perkembangannya, istilah pendidikan atau paedagogie berarti bimbingan atau pertolongan yang diberikan dengan sengaja oleh orang dewasa agar ia menjadi dewasa. Selanjutnya, pendidikan diartikan sebagai usaha yang dijalankan oleh seseorang atau kelompok orang lain agar menjadi dewasa atau mencapai tingkat hidup atau penghidupan yang lebih tinggi dalam arti mental.

Ahmad D. Marimba mengemukakan pendidikan adalah 
bimbingan atau pimpinan secara sadar oleh si pendidik terhadap perkembangan jasmani dan rohani si terdidik menuju terbentuknya kepribadian yang utama. Unsur-unsur yang terdapat dalam pendidikan dalam hal ini adalah: (a) usaha (kegiatan), usaha itu bersifat bimbingan (pimpinan atau pertolongan) dan dilakukan secara sadar; (b) ada pendidik, pembimbing; atau penolong; ada yang dididik atau si terdidik; (c) bimbingan itu mempunyai dasar dan tujuan; dalam usaha itu tentu ada alai-alai yang dipergunakan.

Ki Hajar Dewantara berpendapat bahwa pendidikan yaitu tuntunan di dalam hidup tumbuhnya anak-anak, adapun maksudnya, pendidikan yaitu menuntun segala kekuatan kodrat yang ada. Pada anak-anak itu, agar mereka sebagai manusia, dan sebagai anggota masyarakat dapatlah mencapai keseluruhan dan kebahaginan yang setinggi-tingginya.

Perkembangan berikutnya menurut UU No. 20 tahun 2003 pendidikan adalah usaha sadar dan terencana untuk mewujudkan suasana belajar dan proses pembelajaran agar peserta didik secara aktif mengembangkan potensi dirinya untuk memiliki kekuatan spiritual keagamaan, pengendalian diri, kepribadian, kecerdasan, akhlak mulia, serta keterampilan yang diperlukan dirinya, masyarakat, bangsa, dan negara.

\section{Hakekat Pembelajaran kontekstual (Contextual Teachingand Learning)}

Pembelajaran kontekstual (Contextual Teachingand Learning) konsep belajar yang membantu guru mengkaitkan antara diajarkannya kehidupan dengan situasi dunia nyata siswa dan mendorong siswa membuat hubungan antara pengetahuan yang dimilikinya dengan penerapannya dalam mereka sehari-hari dengan melibatkan tujuh komponen utama. Pembelajaran efektif, yakni: konstruktivisme (Constructivism), pemodelan (Modeling) bertanya (questioning), belajar menemukan (Inquiry), masyarakat belajar (Learning Community), dan penilaian sebenarnya (Authentic Assessment). Menurut Zahorik (1995: 14-22) ada lima elemen yang harus diperhatikan dalam praktek pembelajaran konstektual.

a. Pengaktifan pengetahuan yang sudah ada (activating knowledge). 
Isti Nurhayati

b. Perolehan pengetahuan baru (acquiring knowledge) dengan, cara mempelajari secara keseluruhan dulu, kemudian memperhatikan detailnya. Seleksi dan kombinasi. Pandangan Saussure ini disebut strukturalisime semiotik atau strukturalisme linguistic Jacques Derrida merupakan pengritik linguistik Saussurian. Derrida menunjuk-kan sistem perbedaan yang mewujudkan suatu bahasa tidak bersifat tetap. Suatu petanda (signifer) tidak begitu saja merujuk kepada suatu yang ditandakan (signified), yang ada di kepada seorang pembicara, atau pendengar. Ide atau konsep tentang tempat duduk dengan empat kaki, tidak berpadadan penuh dengan penanda "kursi". Derrida berpendapat bahwa makna suatu istilah selalu bergeser sejalan dengan rangkaian makna yang, mungkin. Yang ditandakan (konsep, makna) selalu ditunda. Tidak ada "makna (signified) transendental". Tak ada makna yang menghentikan arus makna, yang menahan permainan pemaknaan.

c. Pemahaman pengetahuan (understanding knowledge), yaitu dengan cara menyusun (a) konsep sementara (hipotesis), (b) melakukan sharing kepada orang lain agar mendapat tanggapan (validasi) dan alas dasar tanggapan itu (c) konsep tersebut direvisi dan dikembangkan.

d. Mempraktekkan pengetahuan dan pengalaman tersebut (applying knowledge).

e. Melakukan refleksi (reflecting knowledge) terhadap strategi pengembangan pengetahuan tersebut.

\section{Penerapan Pendekatan Kontekstual Di Kelas}

Pendekatan CTL ini memiliki tujuh komponen utama, yaitu konstruktivisme (Construtivism), menemukan (Inquiry), bertanya (Question) masyarakat-belajar (Learning Community), (Modeling), refleksi (Reflection) dan penilaian yang seberiarnya (Authentic Assessment). Sebuah kelas dikatakan menggunakan pendekatan CTL jika menerapkan ketujuh komponen tersebut dalarn pembelajarannya. Dan untuk melaksanakan hal itu tidak sulit CTL dapat diterapkan dalam kurikulum apa saja, bidang studi apa saja, dan kelas yang bagaimanapun keadaannya. Tujuh komponen CTL: 
Implikasi Budaya Sekolah Terhadap Peri Kehidupan Akademis

\section{1) Konstruktivisme (Constructivism)}

Constructivism (konstrukrivisme) merupakan landasan berpikir (filosofi) pendekatan CTL, yaitu bahwa pengetahuan dibangun oleh manusia sedikit demi sedikit, yang hasilnya diperluas melalui konteks yang terbatas (sempit) dan tidak sekonyong-konyong. Pengetahuan bukanlah se-perangkat fakta-fakta, konsep, atau kaidah yang slap untuk diambil dan diingat. Manusia harus mengkonstruksi pengetahuan itu dan memberi makna melalui pengalaman nyata.

Siswa perlu dibiasakan untuk memecahkan masalah, menemukan sesuatu yang berguna bagi dirinya, dan bergelut dengan ide-ide. Guru tidak akan mampu memberikan semua pengetahuan kepada siswa. Siswa harus mengkonstruksikan pengetahuan di benak mereka sendiri. Esensi dari teori konstruktivis adalah ide bahwa siswa harus menemukan dan mentransformasi-kan suatu informasi kompleks ke situasi lain, dan apabila dikehendaki, informasi itu menjadi milik mereka sendiri.

Dengan dasar itu, pembelajaran harus dikemas menjadi proses 'mengkonstruksi' bukan 'menerima' pengetahuan. Dalam proses pembelajaran, siswa membangun sendiri pengetahuan mereka melalui keterlibatan aktif dalam proses belajar dan mengajar. Siswa menjadi pusat kegiatan, bukan guru.

2) Menemukan (Inquiry)

Menemukan merupakan bagian inti dari kegiatan pembelajaran berbasis CTL. Pengetahuan dan keterampilan yang diperoleh siswa diharapkan bukan basil mengingat seperangkat fakta-fakta, tetapi basil dari menemukan sendiri. Guru harus selalu merancang kegiatan yang merujuk pada kegiatan menemukan, apapun materi yang diajarkannya. Topik mengenai adanya dua jenis binatang melata, sudah seharusnya ditemukan sendiri oleh siswa, bukan "menurut buku". Siklus inkuiri: Observasi (Observation), Bertanya (Questioning), Mengajukan dugaan (Hypothesis), Pengumpulan data (Data gathering), Penyimpulan (Conclussion).

3) Bertanya (Questioning)

Pengetahuan yang dimiliki seseorang, selalu bermula dari 'bertanya' 'Sebelum tahu kota Palu, seseorang bertanya "Mana arah ke kota Palu?" Questioning (bertanya) merupakaan strategi utama 
pembelajaran yang berbasis CTL. Bertanya dalam pembelajaran dipandang sebagai kegiatan guru untuk mendorong, membimbing dan menilai kemampuan berpikir siswa. Bagi siswa kegiatan bertanya merupakan bagian pooling dalam melaksanakan pembelajaran yang berbasis inquiri, yaitu menggali informasi, mengkonfirmasikan apa yang sudah diketahui, clan mengarahkan perhatian pads aspek yang belum diketahuinya.

Bagaimanakah penerapannya di kelas? Hampir pada semua aktivitas belajar, questioning dapat diterapkan: antara siswa dengan siswa, antara guru dengan siswa, antara siswa dengan guru, antara siswa dengan orang lain yang didatangkan ke kelas,dan sebagainya. Aktivitas bertanya juga ditemukan ketika siswaberdiskusi, bekerja dalam kelompok, ketika menemui kesulitan, ketika mengamati, dan sebagainya. Kegiatan-kegiatan itu akan menumbuhkan dorongan untuk'bertanya.

4) Masyarakat Belajar (Learning Community)

Konsep learning community menyarankan agar hasil pembelajaran diperoleh dari kerjasama dengan orang lain. Ketika seorang anak barn belajar meraut pinsil dengan peraut elektronik, in bertanya kepada temannya "Bagaimana caranya? Tolong bantu aku!, Lalu temannya yang sudah biasa menunjukkan cara mengoperasikanalat itu. Maka, dua orang anak itu sudah membetuk masyarakat-belajar (learning community).

Hasil belajar diperoleh dari 'sharing' antara teman, antar kelompok, dan antara yang tahu ke yang belum tahu. Di ruang ini, di kelas ini di sekitar sini, juga orang-orang yang ada di luar sana semua adalah anggota masyarakat-belajar.

Dalam kelas CTL, guru disarankan selalu melaksanakan pembelajaran dalam kelompok-kelompok belajar.Siswa dibagi dalam kelompok-kelompok yang anggotanya hiterogen.Yang pandai mengajari yanglemah, yang tahu memberitahu yang belum tahu, cepat menangkap mendorong temannya yang lambat, yang menipunyai gagasan segera memberi usul, dan seterusnya. Kelompok siswa bisa sangat bervariasi bentuknya, balk keanggotaan, jumlah, bahkan bisa melibatkan siswa di kelas atasnya, atau guru melakukan kolaborasi dengan mendatangkan seorang ahli ke kelas. Misalnya tukang 
sablon, petani jagung, peternak susu, teknisi komputer, tukang cat mobil, tukang reparasi kunci, dan sebagainya. "Masyarakat-belajar" bisa terjadi apabila ada proses komunikasi dua arah. "Seorang guru yang mengajari siswanya" bukan contoh masyarakat belajar karena komunikasi hanya terjadi sate arah, yaitu informasi hanya datang dari guru ke arah siswa, tidak ada arus informasi yang perlu dipelajari guru yang datang dari arah siswa. Dalam contoh ini yang belajar hanya siswa bukan guru. Dalam masyarakat belajar, dua kelompok (atau lebih) yang terlibat dalam komunikasi pembelajaran saling belajar. Seseorang yang terlibat dalam kegiatan masyarakat belajar memberi informasi yang diperlukan oleh teman bicaranya dan sekaligus juga meminta informasi yang diperlukan dari teman belajarnya.

Kegiatan saling belajar ini bisa terjadi apabila tidak ada pihak yang dominan dalam komunikasi, tidak ada pihak yang merasa segan untuk bertanya, tidak ada pihak yang menganggap paling tahu, semua pihak saling mendengarkan. Setiap pihak harus merasa bahwa setiap orang lain memiliki pengetahuan yang berbeda yang perlu dipelajari. Kalau setiap orang lain bisa menjadi sumber belajar, dan ini berarti setiap orang akan sangat kaya dengan pengetahuan dan pengalaman.

5) Pemodelan (Modeling)

Komponen CTL selanjutnya adalah pemodelan. Maksudnya, dalam sebuah pembelajaran keterampilan atau pengetahuan tertentu, ada model yang bisa ditiru. Model itu bisa berupa cara mengoperasikan sesuatu, cara melempar bola dalam olah raga, contoh karya tulis, cara melafalkan bahasa Inggris, dan sebagainya. Atau, guru memberi contoh cara mengerjakan sesuatu. Dengan begitu, guru memberi model tentang 'bagaimana cara belajar'.

Sebagian guru memberi contoh tentang cara bekerja sesuatu, sebelum siswa melaksanakan tugas. Misalnya, cara menemukan kata kunci dalam bacaan. Dalam pembelajaran tersebut guru mendemonstrasikan cara menemukan kata kunci dalam bacaan secara cepat dengan menelusuri bacaan secara cepat dengan memanfaatkan gerak mata (scanning). Ketika guru mendemontrasikan cara membaca cepat tersebut, siswa mengamati guru membaca dan membolak batik teks. Gerak mata guru dalam menelusuri bacaan menjadi perhatian utama siswa. Dengan begitu siswa tahubagaimana 
Isti Nurhayati

bacaan clan gerak main yang efektif dalam melakukan scanning.

Kata kunci yang ditemukan guru disampaikan kepada siswa sebagai hasil kegiatan pembelajaran menemukan kata kunci secara cepat. Secara sederhana, kegiatan itu disebut pemodelan. Artinya, ada model yang ditiru dan diamati siswa, sebelum mereka berlatih menemukan kata kunci. Dalam kasus itu, guru menjadi model.

Dalam pendekatan CTL guru bukan satu-satunya model. Model dapat dirancang dengan melibatkan siswa. Sekoring siswa bisa ditunjuk untuk mcmberi contoh temannya cara melafalkan suatu kata. jika kebetulan ada siswa yang pernah memenangkan lomba baca puisi atau memenangkan kontes berbahasa Inggris, siswa itu dapat ditunjuk untuk mendemonstrasikan ke-ahliannya. Siswa 'Contoh' tersebut dikatakan sebagai model. Siswa lain dapat meriggunakan model tersebut sebagai 'standar' kompetensi yang harus dicapainya.

6) Refleksi (Reflection)

Refleksi juga bagian penting dalam pembelajaran dengan pendekatan CTL. Refleksi adalah cara berpikir tentang apa yang telah dipelajari atau berpikir ke belakang tentang apa-apa yang sudah kita lakukan di masa yang lalu. Siswa mengendapkan apa yang baru dipelajarinya sebagai struktur pengetahuan yang baru, yang merupakan pengayaan atau revisi dari pengetahuan sebelumnya. Refleksi merupakan respon terhadap kejadian, aktivitas atau pengetahuan yang baru diterima. Misalnya, ketika pelajaran berakhir, siswa merenung "Kalau begitu, cara saya menyimpan file selama ini salah, ya! Mestinya, dengan cara yang baru saya pelajari ini file komputer saya lebih tertata."

Pengetahuan yang bermakna diperoleh dari proses. Pengetahuan dimiliki siswa diperluas melalui konteks pensbelajaran, yang kemudian diperluas sedikit-demi sedikit. Guru atau orang dewasa membantu siswa membuat hubungan-hubungan antara pengetahuan yang dimiliki sebelumnya dengan pengetahuan yang barn. Dengan begitu, siswa merasa memperoleh sesuatu yang berguna bagi dirinya tentang apa yang barn dipelajarinya. Kunci dari itu semua adalah, bagaimana pengetahuan itu mengendap di benak siswa. Siswa mencatat apa yang sudah dipelajari din bagaimana merasakan ide-ide baru. 


\section{Gambaran SMP Alternatif Qoryah Thoyyibah Salatiga}

\section{a. Sejarah SMP Alternatif Qoryah Toyyibah}

Status dan badan Hukum SMP Qaryah Thayyibah/PKBM: sebelumnya adalah SMP alternatif yang menginduk pada SMP 10 Salatiga, yang proses pembelajaranya adalah sekolah terbuka, karena teknis administratif dan birokrasi yang agak kesulitan, per tahun 2006 memutuskan untuk berpindah pada Program kesetaraan atas saran dari bu Ela Dirjen Kesetaraan, yang dianggap lebih sesuai dengan model pemebelajaran yang ada di Komunitas belajar Qaryah Thayyibah. Badan Hokum Komunitas Belajar Qaryah Thayyibah adalah PKBM yang terdaftar DIKNAS Kota Salatiga pads bulan Nopember 'rahun 2008, dan sudah di legalkan di notaris Ending Murdiati Ungaran pada bulan Desember tahun 2008

SMP Alternatif berdiri tepatnya pada tanggal 13 juni tahun 2003, yang diinisiasi oleh masyarakat dan Bahrudin yang mengundang 31 wali murid berserta muridnya untuk mengagagas sebuah sekolah, yang hadir dan berkomitmen sebanyak 12 anak untuk menyelengggrakan SMP dengan penyebutan SMP alternatif Qoryah Thayyibah, karena terlalu mahalnya pembiayaan di sekolah formal, sehingga muncul gagasan, bagaimana mencoba untuk meyelengarakan pembelajaran tersendiri, yang bisa diselenggarakan lebih murah dan betul-betul sesuai dengan kebutuhan anak.

Gambaran/situasi anak/siswa SMP Qaryah Thayyibah / PKBM QT (angkatan pertama) Hampir keseluruhan anak-anak yang belajar di PKBM Qaryah Thayyibah anak-anak yang lokal, dan sebagian anak luar kola dan orangtua berpenghasilan yang menengah ke bawah, dan usia anak usia sekolah/produktif.

\section{b. Metodologi pembelajaran}

1) Proses belajar, disesuaikan dengan kesepakatan dan perencaanan yang dibuatoleh siswa, pendampinghanya mendampingi clan memfasilitasi yang dibutuhkan siswa (itupun jika betul-betul dibutuhkan).

2) Sitem Penilaian, penilaian kognitif melewati test yang mengedepankan nilai. Penilaian internal anak dengan pembuatan karya dan report sebagai wujud pengembangan diri untuk memantapkan bakat minat dan mengetahui 
Isti Nurhayati

perkembangan apa yang sudah dilakukan masing-masing siswa.

3) Kurikulum yang dipakai, kurikulum nasional dengan mengunakan pendekatan CPL (Contextual Teaching and Learning) untuk menjawab problem masyarakat yang selalu berkembang.

4) Peran Serta Masyarakat, dari sistem yang di bangun untuk wali murid dan komite, sangatlah berkaitan erat karena pembelajaran yang dilakukan adalah belajar dari masalah yang ada sehingga akan semakin memperkuat apa yang terjadi di masyarakat. Kegiatan-etiatan tersebut mencakup:

a) Kegiatan yang dilakukan berbasis masyarakat untuk peningkatan kualitas pendidikan SMP QT.

b) Wawancara dengan masyarakat sesuai materi pembelajaran (seluruh elemen).

c) Bersama-sama penelitian tanah bengkok kalibening, sebagai media pembelajaran akankeberpihakan tanah terhadap pengarap dan kebijakan pemerintah berkaitan dengan tanah desa.

d) Study garden, belajar langsung dengan memnafaatkan lingkungan yang ada (sawah, kebun, lahan perorangan yang dimiliki oleh masyarakat).

e) Bakti sosial yang dilakukan reguler anak-anak tentang lingkungan, dengan bersama-sama operasi plastik di masyarakat untuk mengurangi sampah plastik yang ada, mengolah sampah plastik bersama kaum muda/karang taruna yang ada di masyarkat untuk dijadikan barang yang lebih bermanfaat (tas, sandal, dan kerajinan lain).

SMP Alternatif Qaryah Thoyyibah yang digagas oleh Bahruddin rupanya mengambil filosofi Humanisnik, yaitu menekankan tentang pembebasan dan perubahan menuju yang lebih baik. Pendidikan yang jauh dari komersialisasi atau kapitalisasi pendidikan yang identik dengan ingin bermutu harus membayar mahal. Pendidikan berkualitas tidak harus mahal, maka tugas kita adalah membebaskan kaum lemah dari himpitan ekonomi, terutama menyekolahkan anak-anaknya untuk menyongsong masa depan.

Gagasan segar dan kreatif serta upaya dinamis untuk 
menyelenggarakan model model pendidikan Islam yang excellent, bermartabat, dan menjadi kebanggaan umat serta mampu memberikan jawaban terhadap kebutuhan pendidikan yang dapat melakukan fungsi penyelamatan fitrah sekaligus pengembangan potensi-potensi fitrah manusiawi secara padu dan berimbang.

SMP Alternatif Qaryah Thoyyibah merupakan model pendidikan home schooling yang mampu menyelamatkan sekaligus mengembangkan fitrah manusia membutuhkan perubahan budaya, sikap, dan metode kerja pada segenap warga lembaga pendidikan. Agar warga lembaga pendidikan dapat menghasilkan sesuatu yang berkualitas, maka perlu dipersiapkan lingkungan fisik yang nyaman untuk bekerja efektif dan efisien, sertadorongan kepribadian clan pengakuan terhadap keberhasilan mereka. Kondisi demikian membutuhkan guru yang berperan sebagai fasilitator yang belajar bersama yang mampu menghargai keberhasilan serta dorongan motivasi bagi mereka. Perubahan budaya kerja dapat dilakukan dengan mereformulasi paradigma atau keyakinan (belief) yang dimiliki pimpinan lembaga pendidikan sebagai dinyatakan secara jelas dalam visi lembaga, kemudian dirumuskan dalarn misi dan tujuan institusi, selanjutnya dipahami secara baik oleh segenap warga lembaga pendidikan pada tataran operasional. Paradigma mengajar diubah menjadi paradigma belajar bersama-sama menjadi educationcultural di lembaga ini.

Model pendidikan SMP Alternatif Qaryah Thoyyibah menggunakan pola pembelajaran dengan menerapkan pendekatan situasi belajar yang nyaman (comfortable learning), belajar yang menyenangkan (enjoyfull learning) teori-teori pembelajaran yang berangkat dari lanclasan filosofi konstruktivisine (Constructivism), bertanya (Questioning), menemukan (Inquiry), pemodelan (Modeling), dan penilaian sebenarnya (Authentic Assesment) di antaranya menggunakan Strategi pembelajaran bermakna seperti contextual teaching and learning (mendorong siswa untuk belajar dengan motivasi belajar yang tinggi, belajar sesuai dengan minat, membangun ilmu pengetahuan sesuai dengan konteks lingkungan siswa berada), pembelajaran yang menyenangkan (enjoyful learning), dan pembelajaran bermakna benar-benar terbukti memberikan basil membentuk siswa-siswi yang berkualitas. 
Isti Nurhayati

SMP Alternatif Qaryah Thoyyibah tidak menerapkan aturan yang ketat dan kaku, apalagi hukuman bagi siswa yang tidak mengerjakan pekerjaan rumah, terlambat datang di sekolah, ticlak berseragam. Hal tersebut sama sekali ticlak berlaku di lembaga ini. Suasana belajar selalu riang gembira baik siswa maupun gurunya. Semboyannya adalah "sekolahku adalah rumahku". Siswa bebas untuk mengekspresikan diri, tanpa perasaan canggung mereka latihan presentasi di depan kelas, tidak ada kata salah, yang ada adalah belurn sempurna, bisa diperbaiki kapanpun mereka inginkan menuju pada prestasi puncak, tidak sekedar memenuhi syarat tugas sekolah. Siswa bebas belajar apa saja yang mereka mau, jika jenuh mereka bebas bernyanyi, atau download internet untuk eksplorasi ilmu pengetahuan yang akan menambah ide, pemikiran dan keterampilannya.

Agar siswa smart maka penyampaian pengetahuan bukanlah suatu yang dapat ditransfer begitu saja dari pikiran yang mcmpunyai pengetahuan ke pikiran orang yang belum mempunyai pengetahuan. Bahkan menurut Clasersferld, bila seorang guru bermaksud menstranfer konsep, ide, dan pengertiannya kepada murid, pemindahan itu harus diinterpretasikan dan dikonstruksikan oleh si murid lewat pengalamannya (Bettencourt, 1989). Banyaknya siswa yang salah menangkap apa yang diijarkan oleh gurunya menunjukkan bahwa pengetahuan itu tidak dapat begitu saja dipindahkan, melainkan harus dikonstruksikan atau paling sedikit diinterpretasikan sendiri oleh siswa.

SMP Alternatif Qaryah Thoyyibah menggunakan pendekatan kontekstual (Contextual Teaching and Learning) yang merupakan konsep belajar yang membantu guru mengkaitkan antara materi yang diajarkannya dengan situasi dunia nyata siswa dan mendorong siswa membuat hubungan antara pengetahuan yang dimilikinya dengan penerapannya dalam kehidupan mereka sebagai anggota keluarga dan masyarakat. Dengan konsep itu, hasil pembelajaran diharapkan lebih bermakna bagi siswa. Proses pembelajaran berlangsung alamiah dalam bentuk kegiatan siswa bekerja dan mengalami, bukan transfer pengetahuan dari guru ke siswa. Strategi pembelajaran lebih dipentingkan daripada basil.

Oleh karena itu SMP Alternatif Qaryah Thoyyibah tidak 
membatasi ruang gerak para siswa dengan mengadopsi prinsip belajar tidak hanya di ruang kelas. Para siswa dapat menyatu dengan alam, mereka bisa menghabiskan waktuya untuk menjawab pertanyaanpertanyaan yang mengganjal di benaknya di kebun tomat, mencatat, memotret dan memakan buah segar dikebun.

Dilihat dari segi bangunanya, sekolah inipun tanpa pagar pembatas sehingga komunikasi para siswa dengan masyarakat sekitar tidak terbatasi. Lingkungan sekolah, sawah, ladang, pasar, rumahrumah penduduk merupakan laboratorium alami bagi mereka. Tidak ada batas ruang dan waktu yang akan membatasi mereka untuk berekspresi dan berkreatifitas dalam belajar. Lingkungan pendidikan di masyarakat merupakan education-ecosystem.

Dalam konteks itu, siswa perlu mengerti apa makna belajar, apa manfaatnya, dalam status apa mereka, dan bagaimana mencapainya. Mereka sadar bahwa yang mereka pelajari berguna bagi kehidupannya nanti. Dengan begitu mereka memposisikan sebagai diri-sendiri yang memerlukan suatu bekal untuk hidupnya nanti. Mereka mempelajari apa yang bermanfaat bagi dirinya dan berupaya menggapainya. Dalam upaya itu, mereka memerlukan guru sebagai pengarah dan pembimbing.

Fina salah satu siswi SMP Qaryah Thayyibah yang bercitacita menjadi presenter ini, motivasinya belajarnya begitu kuat. Fina menjuarai lomba pidato di Salatiga mengalahkan guru SMA dan mahasiswa. Fina menemukan makna belajar tanpa tekanan dari manapun, belajar sudah merupakan "makanan" sehari-hari yang dilakukan dengan perasaan gembira. Fina menyadari bahwa pengetahuan dan keterampilan tidak dapat hanya diperoleh dari guru. Guru hanya membimbingnya beberapa langkah selanjutnya ia mencarinya sendiri lewat lingkungan sekitar sebagai sumber belajar. Kebun, pedagang, dokter, perangkat desa, internet, perpustakaan adalah sumber belajar yang tidak akan habis mereka gali.

Dalam kelas kontekstual, tugas guru adalah membantu siswa mencapai tujuannya. Maksudnya, guru lebih banyak berurusan dengan strategi daripada memberi informasi. Tugas guru mengelola kelas sebagai sebuah tim yang bekerja bersama untuk menemukan sesuatu yang barn bagi anggota kelas (siswa). Kontekstual hanya 
sebuah strategi pembelajaran. Seperti halnya strategi pembelajaran yang lain, kontekstual dikembangkan dengan tujuan agar pembelajaran berjalan lebih produktif dan bermakna. Pendekatan kontekstual dapat dijalankan tanpa harus mengubah kurikulum dan tatanan yang ada.

Sejauh ini pendidikan kita masih didominasi oleh pandangan bahwa pengetahuan sebagai perangkat fakta-fakta yang harus dihafal. Kelas masih berfokus pada guru sebagai sumber utama pengetahuan, kemudian ceramah menjadi pilihan utama strategi belajar. Untuk itu, diperlukan sebuah strategi belajar yang 'ideal' yang lebih memberdayakan siswa. Sebuah strategi belajar yang tidak mengharuskan siswa menghafal fakta-fakta, tetapi sebuah strategi yang mendorong siswa mengkonstruksikan pengetahuan di benak mereka sendiri.

Untuk menjadikan siswa smart dapat ditambahkan dengan menerapkan teknologi pendidikan. Teknologi dalam pendidikan adalah penggunaan teknologi sebagai produk untuk membantu penyelenggaraan kegiatan pendidikan, termasuk misalnya penggunaan perangkat komputer, laptop, kamera, kamera handycam, LCD, pengeras suara dan lain-lain peralatan atau perangkat keras untuk keperluan terselenggaranya kegiatan pendidikan. Sedangkan teknologi pendidikan adalah suatu proses yang bersistem dalam usaha mendidik atau membelajarkan. Dalam proses yang bersistem ini kemungkinan besar memang digunakan teknologi sebagai produk.

Menulis buku, menulis naskah pidato dalam bahasa Inggris, membuat karya film merupakan keterampilan yang dipraktikan sehari -hari di sekolah ini. Mereka tidak belajar dari gurunya. Pengetahuan menulis dan membuat film mereka dapatkan dari eksplorasi lewat internet. Tidak peduli pagi, siang atau malam hari mereka terus belajar tanpa disuruh-suruh oleh orang tua atau gurunya. Achievement (motivasi untuk berprestasi) secara intrisik selalu muncul di dada siswa-siswi SMP Alternatif Qaryah Thayyibah Kalibening Salatiga.

\section{Simpulan}

Pendidikan di SMP AlternatifQaryah Thayyibah menekankan bahwa anak akan belajar lebih balk jika lingkungan diciptakan 
alamiah. Belajar akan lebih bermakna jika anak 'mengalami' apa yang dipelajarinya, bukan 'mengetahui'-nya. Pembelajaran yang berorientasi target penguasaan materi terbukti berhasil dalam 'kompetisi' mengingat dalam jangka pendek, tetapi gagal) dalam membekali anak memecahkan persoalan dalam kehidupan jangka panjang.

Dihadapkan pada aturan-aturan yang jelas yang ditetapkan lebih dulu secara ketat. Pembiasaan (disiplin) sangat esensial. Dalam prespektif pembelajaran yang humanis, siswa hendaknya dihadapkan kepada lingkungan bclajar yang bebas. Kebebasan merupakan unsur yang sangat esensial kebebasan dipandang sebagai penentu keberhasilan.

Dalam konsep pendidikan kovensional kegagalan atau ketidakmampuan dalam menambah pengetahuan sebagai kesalahan yang wajib mendapatkan hukuman. Sebaliknya keberhasilan atau kemampuan dikategorikan sebagai bentuk perilaku yang pantas dipuji atau diberi hadiah. Konsep pendidikan humanistik mengisyaratkan bahwa kegagalan atau keberhasilan, kemampuan atau ketidakmampuan dilihat sebagai interpretasi yang berbeda yang perlu dihargai. Tujuan pembelajaran menekankan pada penambahan pengetahuan. Seseorang dikatakan telah belajar apabila mampu mengungkapkan kembali apa yang telah dipelajari.

Budaya pendidikan yang dibangun di SMP Alternatif Qaryah Thayyibah adalah tertanamnya sebuah konsep pendidikan humanis, kebebasan dipandang sebagai penentu keberhasilan, kontrol belajar dipegang oleh si-belajar. Budaya pendidikan berikutnya adalah kebebasan yang merupakan unsur esensial yang dialami para siswa dalam lingkungan belajar.

Education-cultural di atas berdampak pada pembentukan kepribadian siswa yang terdiri dari pengetahuan, ketrampilan Berta sikap siswa yang unggul. Selain prestasi akademik yang menonjol, achievement yang tinggi, keterampilan dan kreativitasnya unggul dan produktif. Para siswa di sini sangat percaya diri, toleran, dan sangat peduli dengan lingkungan. Karena mereka dididik untuk bersinergi dengan lingkungan alam, masyarakat sebagai educative-ecosystem yang seimbang. 
Isti Nurhayati

Pendidikan di SMP Alternatif Qaryah Thayyibah ini memiliki pandangan tentang pendidikan sebagai berikut.

a. Tujuan pendidikan dan proses pendidikan berasal dari anak (siswa). Oleh karenanya kurikulum dan tujuan pendidikan menyesuaikan dengan kebutuhan, minat dan prakarsa anak.

b. Siswa perlu mengerti apa makna belajar, apa manfaatnya, dalam status apa mereka, dan bagaimana mencapainya. Mereka sadar bahwa yang mereka pelajari berguna bagi kehidupannya nanti.

c. Siswa adalah anak didik yang aktif bukan pasif. Anak memiliki keinginan belajar dan akan melakukan aktivitas belajar apabila mereka tidak difrustasikan belajarnya oleh orang dewasa atau penguasa yang memaksakan keinginannya.

d. Siswa memposisikan sebagai diri-sendiri yang memerlukan suatu bekal untuk hidupnya nanti. Mereka mempelajari apa yang bermanfaat bagi dirinya dan berupaya menggapainya. Dalam upaya itu, mereka memerlukan guru sebagai pengarah dan pembimbing.

e. Peran guru adalah sebagai teman belajar bukan penguasa kelas. 'tugas guru membantu siswa belajar, sehingga siswa memiliki kemandiriandalam belajar. Guru berperan sebagai pembimbing dan yang melakukan kegiatan mencari dan menemukan pengetahuan bersama siswa. Tidak boleh ada pengajaran yang bersifat otoriter, di mana guru sebagai penguasa dan murid menyesuaikan.

f. Sekolah sebagai bentuk kecil dari masyarakat luas. Pendidikan seharusnya tidak sekedar dibatasi sebagai kegiatan di dalam kelas dengan dibatasi empat dinding sehingga terpisah dari masyarakat luas. Karena pendidikan yang bermakna adalah apabila pendidikan itu dapat dimanfaatkan dalam kehidupan masyarakat.

g. Aktivitas belajar harus terfokus pada pemecahan masalah, bukan sekedar mengajarkan mata pelajaran. Pemecahan masalah adalah bagian dari kegiatan kehidupan oleh karenanya pendidikan harus membangun kemajuan siswa untuk memecahkan masalah. Kegiatan pendidikan bukan sebagai pemberian informasi atau data dari guru pada siswa 
yang terbatas sebagai aktivitas mengumpulkan dan mengingat kembali pengetahuan statis.

h. Tugas guru mengelola kelas sebagai sebuah tim yang bekerja bersama untuk menemukan sesuatu yang barn bagi anggota kelas (siswa). sesuatu yang barn (pengetahuan dan keterampilan dan sikap) datang dari 'menemukan sendiri', bukan dari 'apa kata guru'.

i. Iklim sekolah harus demokratis dan kooperatif. Karena kehidupan di masyarakat selalu hidup bersama dengan orang lain, maka setiap orang harus mampu membangun kooperasi dengan orang lain. Namun dalam sistem pendidikan tradisional, siswa sering dilarang untuk berbicara, berpindah tempat, atau bekerjasama dengan siswa lain. Iklim demokratis dalam kelas adalah dibutuhkan agar siswa dapat hidup secara demokratis di masyarakat.

Pendidikan pragmatic-modern telah gagal membawa misi kemanusiaan. Lembaga pendidikan Islam di luar pesantren yang pada awalnya diharapkan menjadi media alternatif, pada perkembangannya justru dianggap tidak mampu menjaga harapan itu. Kebijaksanaan pendidikan yang bersifat kognitif (dengan asumsi, bahwa pemahaman keilmuan yang mendalam akan melahirkan perilaku agamis yang bisa dipertanggungjawabkan secara ilmiah), pada akhirnya justru melahirkan produk yang menguasai secara ilmiah, tetapi sering dipertanyakan dari segi penghayatan (amaliyah).

Konsep pendidikan Humanis-Religius itu sebenarnya berangkat dari pandangan bahwa manusia itu makhluk yang utuh, humanistik, dan komprehensif. Struktur manusia terdiri alas dua komponen yang berbeda tetapi saling terkait. Dua komponen itu adalah fisik-non fisik, material-spiritual, jasmani-rohani, akalmoral dan seterusnya. Inilah yang dimaksud sebagai manusia seutuhnya. Manusia yang mencakup kebutuhan kognitif, afektif, dan psikomotorik. Jadi, sebetulnya di tingkat filosofi, tujuan pendidikan nasional, yakni membentuk manusia seutuhnya itu sudah betul. 
Isti Nurhayati

\section{DAFTAR PUSTAKA}

Anderman, Eric M \& Maher Martin L. 1994. Motivation and Schooling in The Middle Grades Review of Education Research. Vol 64, No.2, pp. 287 - 309.

Ballard, Brigid \& Clanchy,John. 1984. Study Abroad: A Manualfor Asian Students. Selangor Darul Ehsan: Longman Malaysia SUN. BHD.

Biggs, John B. 1985. “The Role of Metalearning Study Process”, British Journal of Educational Psychology, 55,185-212.

Bandura, A. 1976. Social Learning Theory. Englewood Cliffs, N.J.: Prentice - Hall.

Bredekamp. Sue. 1987. Developmentally Appropriate Practice it? Early Childhood Program Serving Children Front Birth Trough Age 8. Washington: NAEYC.

Chaplin, C.P. 1989. Kamus Lengkap Psikologi. Terjemahan Kartini Kartono. Jakarta: Rajawali Pers.

Davies, Ivor K. 1986. Pengelolaan Belajar. Tcrcinahan Sudiro Sudirjo Jakarta: CV Rajawali.

Departemen Pedidikan Nasional. 2002. Pendekatan Kontekstual (Contextual Teaching and Learning (CTL). Direktorat Jendral Pendidikan Dasar dan Menengah. Direktorat Pendidikan Lanjutan Pertama.

Elida Prayitno. 1989. Motivasi Dalanz Belajar. Jakarta: Dikjen Dikti Depdikbud.

Gagne, RM. 1970. The Conditions of Learning. New York: Holt, Renchart and Winston.

Gagne, Robert M, Driscoll, Marcy Perkins. 1989. Ewnstials of Learning for Instruction. New Jersey: Prentice Hall.

Good, Thomas L., Brophy, Jere E. 1990. Educational Psychology, A Realistic Approach. New York: Longman.

Gredler, Margaret E. Bell. 1991. Belajar dan Membelajarkan. Diterjemahkan oleh Munandir. Seri Pustaka Teknologi 
Pendidikan No. 11. Jakarta: Rajawali.

Lorsbach, A. \& 'robin, K. 1992. "Constructivisni as a Referent for

Science Teaching". NARST Research Matters - To The Science Teacher No..

Nyoman S. Degeng. 2000. "Konstruktivistik - Sebuah Tawaran Petnbelqjaran Masa Depan”. Makalah kuliah perdana Pascasarjana UNS Surakarta.

Paul Suparno. 1997. Fisafat Konstruktivispne dalain Pendidikan. Pustaka Filsafat. Yogyakarta: Kanisius.

Peaget, J. 1971. Psychology and Epistemology. New York: The Viking Press.

Hall, Calvin S.\& Linddney, Gardner,.1981.Theories of Personality. New York: John Wiley and Sons.

Hidi, Suzanne \& Harackiewicz, Judith M. 2000.” Motivating The Academically Unmotivated". A Critical Issue for The 21stCentury. Vol 70, No.2, pp. 151-179.

Hidi, Suzanne. 1990." Interest and Its Contribution as a Mental Resource for Learning" Review of Education Research. , Vol 60, No.4, pp. $159-571$.

Joyce, Bruce \& Weil, Marsha. 1994. Models of Teaching. Second Edition. London: Prentice-Hall International, Inc.

Kuncaraningrat. 1990. Pengantar Units Antropologi. Jakarta: PT Rineka Cipta.

Merril, M. David, Whitchell, David G. 1994. Instructional Design Theory. New Jersey: Prentice Hall.

Muhibbin Syah. 1997. Psikologi Pendidikan: Suatu Pendekatan Baru. Bandung: PT Remaja Rosdakarya, Rosda Group.

Moh. Surya. 1982. Psikologi Pendidikan. Cetakan Ketiga. Bandung: FIPIKIP.

Mudjiono. 1992. Strategi Belajar Mengajar. Jakarta: Dirjen Pendidikan

Reigeluth, Charles M. 1983. Instructional-Design 77ieories And Models: Ar? Overview of Their Current Status. London: Lawrence Erlbaum Associates Publishers. 
Isti Nurhayati

Sardinian, A.M. 1994. Interaksi dan Motivasi Belajar Mengajeir: Pedontan Guru dan Colon Guru. Jakarta: fyl'Raja Grafindo Persada.

Skinner, B.F. 1969. 77ie Technology of 77 teaching. New York: W.W. Norton.

Shapiro, B, 1994. MiatChildren Bring to Light: A Constructivist Perspective on Children's Learning in Science. Ny: Teachers College Press. Spraedley, James P. 1997. Metode Etnografi. Yogyakarta: PT Tiara Wacana Yogya.

Sugiyono. 2007. Metode Penelitian Pendidikan, Pendekatan Kilantitatif Kualitalif, dan R\&D. Bandung: Alfabeta.

Von Glasersfeld, E. 1992. "Questions and Answers ABOUT Radical Constructivisin. In M. Pearsall (Ed.)”. Relevant Research. Scope, Squence, and Coordinalion of Secondary School Science. (Vol. 11, 169 -182). Washington DC: NSTA.

Siti Rahayu Haditono. 1979. Achievement Motivation, Parents Educational Level And Child Rearing Practice in Four Occupational Groups, Yogyakarta: Fakultas Psikologi Universitas Gajah Mada,

Woolfolk, Anita E. \& Nicolich, Lorranie McCune. 1989. Educational Psychology for Teacher. New Jersey: Prentice Hall. 